\title{
Roman mining on Exmoor: a geomorphological approach at Anstey's Combe, Dulverton
}

\section{Antony Brown, Jenny Bennett and Edward Rhodes}

A survey of valley fills in south-facing combes (headwater valleys) along the south side of the Exmoor massif revealed an anomalously deep infill in one valley. This infill of up to $5 \mathrm{~m}$ depth had been gullied revealing a complex stratigraphy. Studies of the stratigraphy, clast orientation and shape suggested several accumulation episodes under different environmental conditions commencing in a periglacial climatic regime. Later units included sandy silts which can be dated using optically stimulated luminescence (OSL) of quartz grains. The OSL dates, indicate that the inter-gravel silts accumulated in two periods, the Romano-British period and the 16th-17th centuries AD. A survey of the very small valley catchment revealed a linear trench of a type associated with early iron mining. Given the anomalously high volume of accumulated sediment from such a small catchment and evidence of mining on the slope above the site, the geomorphic mechanism is almost certainly the downslope transport of mining debris from the slope to the valley floor. This study suggests that the systematic survey of headwater valleys in metalliferous uplands may be one way of locating areas of early mining activity and that such deposits could provide a chronology of working and abandonment.

Keywords: iron mining, alluviation, gullying, upland landscapes, OSL

\section{Introduction}

Over the last two decades it has been realised that geomorphological studies of alluvial sediments can provide data concerning early mining which cannot always be gained from archaeological surveys or excavations of mining sites. Many geomorphological studies have shown how mining has transformed (infilled) river valleys in the historical period due to an excessive supply of sediment (Gilbert 1917; Macklin et al. 1992; Marron 1992; Knighton 1991; Hudson-Edwards et al. 1999a) in addition to, or even overwhelming other human-impacts and climatic influences (Brown 1997). These observations are now being simulated using mathematical modelling (Coulthard and Macklin 2003) and sedimentological studies have become an approach to the study of ancient mining (Hudson et al. 1999b; Brown et al.

Tony Brown (corresponding author), Department of Geography, School of Geography, University of Southampton, Highfield Campus, Southampton SO17 1BJ, UK; e-mail: Tony.Brown@ soton.ac.uk; Jenny Bennett, School of Geography, Archaeology and Earth Resources, University of Exeter, Exeter EX4 1RJ, UK; Edward Rhodes, Department of Environmental and Geographical Sciences, Manchester Metropolitan University, Chester Street, Manchester M1 5GD, UK
2003). This methodology has been applied to Prehistoric and Romano-British tin mining in Exmoor and Dartmoor (Brown et al. 2003; Thorndycraft et al. 1999; 2003; 2004), lead mining in the Mendips (Macklin 1985) and Biggar, Southern Scotland (Rowan et al. 1995) and gold mining in the Slieve Bloom Mountains, Ireland (Gallagher and Thorpe 1995). The research findings reported here result from a search for alluvial sequences within the Exe Basin in order to identify interactions between climate and anthropogenic forcing (Bennett et al. in press). The anomalous nature of the deposits at Anstey's Combe required further investigation with the aim of explaining within-basin variation and identifying the forcing mechanism.

Exmoor has many areas of mineralisation which have been exploited from the medieval period to the 20th century for iron, silver-lead, copper and gold (Dines 1956; Atkinson 1997). Archaeological studies, most notably under the Exmoor Iron Project, have excavated a number of processing sites including Brayford, Sherracombe Ford and Horner Wood (Fig. 1), providing evidence, including both 

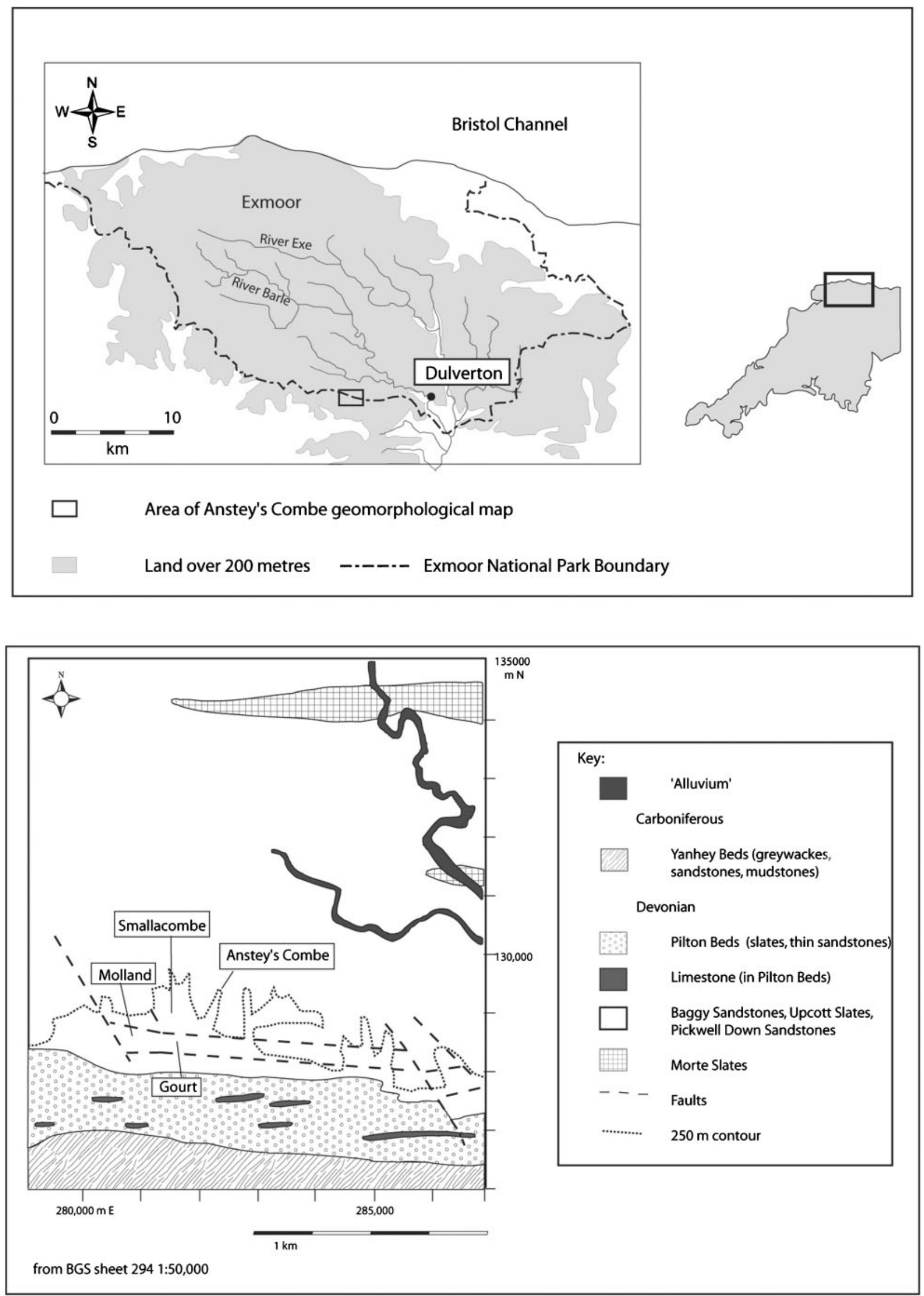

Figure 1 Location map (top) and geology of the area (bottom) 
processing areas and slag heaps, of iron smelting during the late Iron Age and Romano-British period (Juleff 1997; 2000; Riley and Wilson-North 2001). Many other slag heaps of probably late Iron Age or Romano-British age are also known including Timberscombe and Sindercombe (Riley and WilsonNorth 2001). As yet the sites of extraction remain uncertain. Work at Roman Lode suggests that it could be an ore extraction site in the Romano-British period (Sellick 1970; Juleff and Bray 2007) and a Roman age for the Colton Pits site has been suggested (Riley and Wilson-North 2001), but as yet there is no firm dating control on either of these sites. The present study uses the comparative analysis of valley fills in adjacent small valleys to identify anomalous alluvial deposits which were then mapped, logged and dated using optically stimulated luminescence. In very small headwater valleys on identical geology with almost identical geomorphology (slope form, angles, etc.) differential sedimentation could be caused either by massive variations in vegetation and land use history, or by mining activity. On upland marginal land, arable cultivation has been at most episodic and should be recognisable in the sedimentary characteristics of colluvial and alluvial sediments (Brown in press).

\section{Anstey's Combe anomalous valley fill}

Six very similar combes (Triss Combe, Smallacombe, Gourt Mires Combe, Anstey's Combe, Brimblecombe and Ringcombe) drain from the southern slope of the ridge from Molland Common to East Anstey Common (Fig. 1). The similarities in topography are illustrated on Table 1 with Anstey's Combe being the smallest, but very similar in catchment size (e.g. length), stream length, and valley depth. They all also have very similar drainage areas with Anstey's Combe being the smallest at $0.4 \mathrm{~km}^{2}$. In five of these combes, there were on average 1-2 $\mathrm{m}$ of exposed deposits (by stream erosion) at the base of the valley resting upon bedrock and no gully incision into the valley floor. These deposits consisted of a fining upward deposit from basal sandy gravel to silty sand with occasional stones and with no laterally extensive erosional bounding surfaces or sedimentary structures. However, at Anstey's Coombe just under
$6 \mathrm{~m}$ was exposed by gully incision into the combe floor. There is a deep gully, significant enough to be named by the Ordnance Survey as Anstey's Gully, at the southern end of the combe, approximately at the boundary of the National Park. This contrasts with the neighbouring combes to the east and west, none of which have been alluviated or incised to the same extent. The bedrock of the ridge consists of Devonian and Carboniferous sandstones and shales (Institute of Geological Sciences 1969; Edwards 2000, fig. 1). These rocks show folding and faulting as a result of pressure exerted from the south during the Variscan orogeny in the late Carboniferous $(\sim 300 \mathrm{Ma})$. Anstey's Combe lies just north of the east-west trending Brushford fault system. In the Tertiary period these faults were reactivated during the Alpine Orogeny and with the Miocene (24-12 Ma) uplift of the Exmoor block (Straw 1995). This involved movement along both these major fault zones and related smaller north-west-south-east trending faults. Anstey's Combe is underlain by the Pickwell Down Sandstone, a coarse pinkish sandstone with quartz veining along fractures that breaks readily into flat clasts. Slight metamorphism of sandstones is present which is associated in this area with concentrations of metalliferous ores, mainly of copper and iron (Edwards 2000).

Fig. 2 shows the geomorphology of the area and Anstey's Gully itself in more detail. Faulting and folding of bedrock has influenced the general form of these south-facing valleys which are similar in both form and catchment area. Anstey's Combe differs from the neighbouring combes only in that the valley is more constricted and deeply gullied (Anstey's Gully). The northern end of the neighbouring combe to the west (Gourt Mires) contains a mire $150 \mathrm{~m}$ wide and there is a narrower mire $(\sim 10 \mathrm{~m}$ wide $)$ at the northern end of Anstey's Combe. At its upstream end, Anstey's Gully is about $1 \mathrm{~m}$ deep, increasing downstream to just under $5 \mathrm{~m}$ before shallowing again to $1 \mathrm{~m}$ at the southern end. There are two side gullies to the east, and a raised embankment to the south of the lower side-gully. An ephemeral stream flows into the gully from the combe, and a spring is also present in the gully itself as the valley floor

Table 1 Topographic indices for the combes on the south side of Anstey's Ridge, Exmoor

\begin{tabular}{lllr}
\hline Combe & Catchment length(km) & Stream length(km) & Valley depth(m) \\
\hline Anstey's Combe & 0.775 & 0.30 & 85 \\
Gourt Mires Combe & 0.850 & 0.22 & 90 \\
Smallacombe & 1.250 & 0.32 & 130 \\
Triss Combe & 1.540 & 1.20 & 135 \\
\hline
\end{tabular}




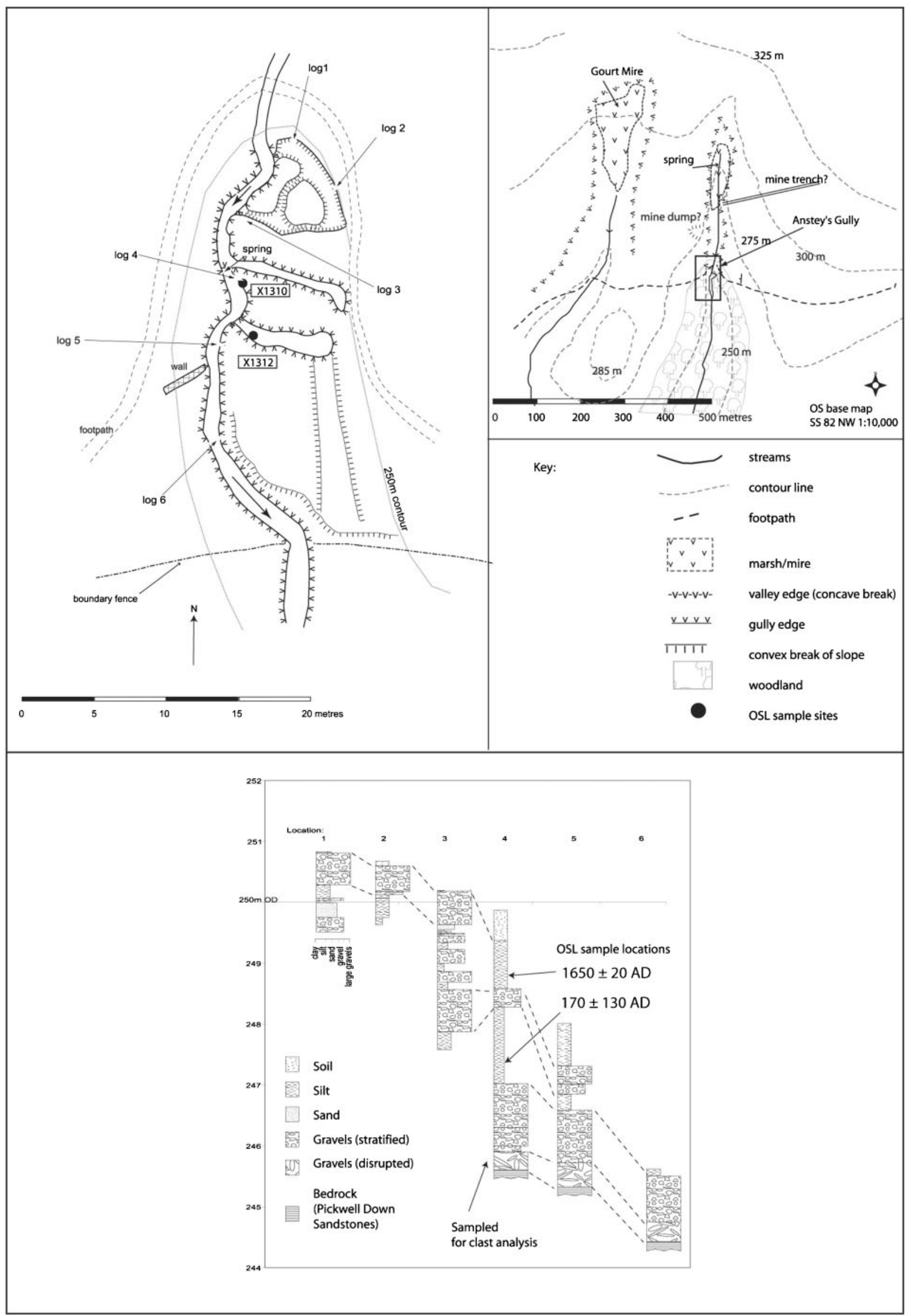

Figure 2 Location of the sections, generalised stratigraphy of the gully faces and detailed long section of the stratigraphy with the OSL sample locations 
deposits form a perched aquifer. The southern part of the gully is heavily wooded and outside the National Park boundary.

\section{Methods}

A geomorphological survey was undertaken of the small combes that drain the southernmost plateau of the Exmoor massif to locate thick sedimentary sequences with the potential for palaeoenvironmental reconstruction, hydrogeomorphological analyses and the identification of mining sites. Sediments in exposures were surveyed using a total station and logged using standard geological procedures, with bulk samples taken for dating and geochemical analysis. Clast lithological analysis was also conducted using a reference set derived from the North Devon area and checked through collaboration with the British Geological Survey.

Loss-on-ignition of the organic-rich silts $(<10 \%$ LOI) revealed no interstratified organic material suitable for ${ }^{14} \mathrm{C}$ dating, so it was decided to apply optically stimulated luminescence (OSL) to suitable beds within the sedimentary sequence. Two OSL samples were collected from location 4 , one from the lower silts, and the second from a side gully that correlates with the upper silt (see Fig. 2). The OSL dating samples were collected by driving opaque PVC tubes into the cleaned vertical profile. After removal of the sampling tube, a water content sample was collected, and the hole deepened to $30 \mathrm{~cm}$ using a small hand auger. In-situ measurements were made at each sampling location using an EGandG Ortec portable microNomad multichannel NaI gamma spectrometer. These measurements were used to calculate total gamma dose rate using the threshold method, and based on calibration in concrete blocks doped with radioisotopes (Rhodes and Schwenninger 2007). The samples were transported in their tubes to the Research Laboratory for Archaeology and the History of Art (RLAHA), University of Oxford, where they were prepared and measured. The tubes were opened under controlled laboratory lighting which was used for all subsequent treatments, and the outer 1 to $2 \mathrm{~cm}$ from both ends of each tube was set aside for density and water content determinations, and NAA measurement. All the NAA measurements of $\mathrm{U}$, Th and $\mathrm{K}$ share a $5 \%$ uncertainty in the age calculations but have been omitted from the table for clarity, following the archaeological protocol published by Duller (2008). For OSL measurements, sediment from the inner part of each tube was treated with dilute $\mathrm{HCl}$ to remove carbonate and disaggregate grains. Samples were then wet sieved, and grains of between 125 and $180 \mu \mathrm{m}$ were treated in concentrated $(40 \%) \mathrm{HF}$ with a small volume of additional concentrated $\mathrm{HCl}$ and continuously agitated for around 100 minutes. This treatment is to remove feldspar grains and to etch the surface of each quartz grain, and the $\mathrm{HCl}$ is designed to prevent the precipitation of fluorides. After rinsing, each sample was dried and heavy minerals were removed using sodium polytungstate solution with a density of $2.68 \mathrm{~g} \mathrm{~cm}^{-3}$. The remaining fraction was thoroughly rinsed and dried, and sieved a second time to remove grains smaller than $125 \mu \mathrm{m}$. Grains were mounted on $9.7 \mathrm{~mm}$ diameter aluminium discs using a viscous silicone oil, with the sample covering approximately the central $5 \mathrm{~mm}$, corresponding to around 600 grains per aliquot.

OSL measurements were made at RLAHA, Oxford, UK, in February 2003, using a SAR protocol (Murray and Wintle 2000; 2003) comprising 12 aliquots for each sample. Measurements were made in a modified Risø TL-DA-10 automated reader, fitted with an array of Nichia blue light-emitting diode (LED) arrays providing up to $16 \mathrm{~mW} \mathrm{~cm}^{-2}$ intensity respectively. These LEDs were filtered using Schott GG420 filters, providing peak stimulation wavelength of $470 \Delta 20 \mathrm{~nm}$. All SAR measurements incorporated a $10 \mathrm{~s} 220^{\circ} \mathrm{C}$ preheat before OSL measurement of the natural and regenerated OSL signals, and a $10 \mathrm{~s}$ heat of $200^{\circ} \mathrm{C}$ before each sensitivity determination OSL measurement, following the procedures presented by Rhodes et al. (2003). Each SAR measurement included 7 cycles, comprising natural OSL measurement, 4 regenerative dose points, a zero point for thermal transfer determination, and a repeat of the first regenerative dose point, to assess sensitivity correction (Murray and Wintle 2003). OSL was measured for $50 \mathrm{~s}$ at $125^{\circ} \mathrm{C}$ for every determination. Every OSL measurement was preceded by a $10 \mathrm{~s}$ infra-red stimulated luminescence (IRSL) measurement at $60^{\circ} \mathrm{C}$, to help reduce the $\mathrm{OSL}$ signals of any residual feldspar grains or inclusions (Banerjee et al. 2001).

Age calculation followed the methods described by Rhodes et al. (2003). In-situ NaI gamma spectrometry values were used for the gamma dose rate, while beta dose rates were based on Neutron Activation Analysis (NAA) measurements of $10 \mathrm{~g}$ of dry sediment from within each sample tube. A water content value of $20 \pm 5 \%$ was used, based on field observations and laboratory measurements. Table 2 provides sample details, dose rate contributions and age estimates, presented in years AD with 
associated 1 sigma uncertainties. The low error on sample X1312 arises from the small uncertainty on the parameters involved.

\section{Stratigraphy, sedimentology and dating}

The sides of Anstey's gully expose stratified silts and gravels, varying from 1 to just under $5 \mathrm{~m}$ in thickness. The stratigraphic sections show alternating beds of gravel and silt with some organic-rich layers within the silts. The general sequence is a basal massive boulder-pebble gravel resting unconformably on the Pickwell Down Sandstone under 4 m of thick, weakly stratified, moderately sorted, matrix-supported gravel (Fig. 2). The basal boulder gravel is matrix-supported and in sections 4-6 showed some high-angle orientations typical of disrupted cryoturbated deposits and the infilling of dry valleys formed through periglacial processes (Goudie and Parker 1996). This gravel unit is interrupted by a well-sorted sandy-silt unit which then overlies the gravels in some of the sections. Clast orientation analysis of the lower gravel unit confirms that there is a wide variation of orientation and dip but with a slight preference for a north-west orientation which is the same as the alignment of the valley. This variable orientation is typical of alluvial fans and cones (Harvey et al. 2005) but constrained within a relatively narrow valley. Also visible in the lower unit was evidence of matrix disruption and the movement of clasts within the matrix. The sandy silts were horizontally bedded with fine-grained silty organic matter suggesting some degree of syndepositional soil formation. Clast lithological analysis showed all the clasts to be of local origin - either Pickwell Down Sandstone or quartz vein material. Clast form and shape analysis (Fig. 3) showed blade and discs were the most common clast forms reflecting the tendency of the bedrock to fragment along bedding planes into flat discs or blades, and clasts were predominantly sub-angular to subrounded in shape indicating that relatively little transport has occurred given the highly abradable nature of the sandstone. Also observed was a large variation in colour from a typical yellow-brown (7.5YR 4/4) at the base of sections such as section 3 to a bright orange-red (10R 4/6) in the overlying units until the modern soil was encountered. The sedimentary characteristics described above, the location of the deposits where the narrow valley opens out and the inferred increase in bedrock head gradient (probably a buried knickpoint) all suggest that the gravels were formed as an alluvial fan or cone.

The OSL dates obtained are shown in Table 2. Both samples displayed intense, rapidly decaying 

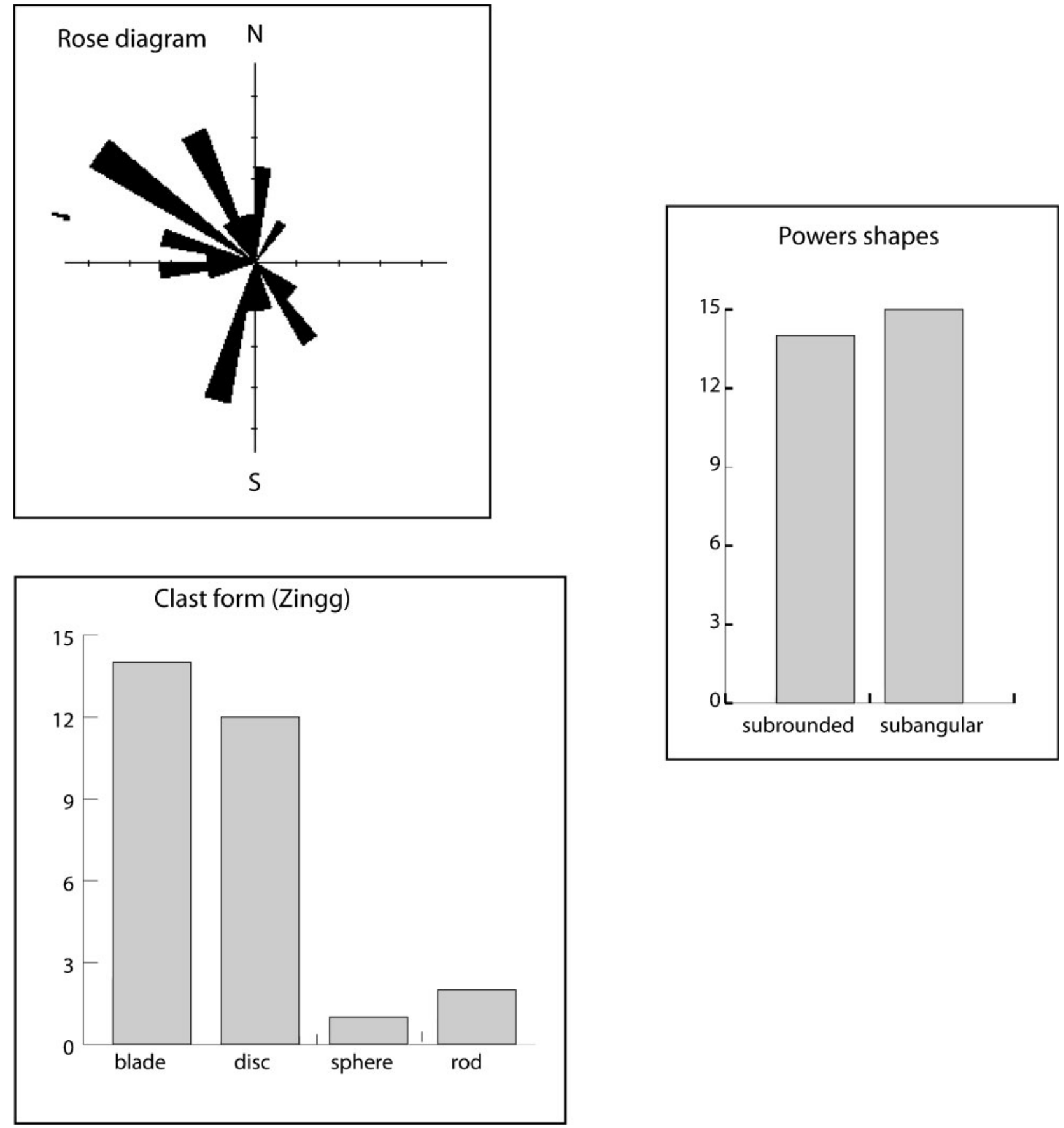

Figure 3 Clast shape and forms from the basal disrupted gravel (see Fig. 2)

OSL signals (Fig. 4), and displayed excellent recycling values (X1310: mean value 1.00; X1312: mean value 0.99) and low thermal transfer values (X1310: $0.6 \%$ of the natural OSL; X1312: $2 \cdot 0 \%$ ). Asymmetrical equivalent dose distributions were observed for both samples (Fig. 5), with high dose values extending from a lower group. Numerical modelling suggests that equivalent dose distributions such as this for multiple grain aliquots are caused by the incorporation of a proportion of grains with dose values higher than the others (Rhodes 2007). In these sedimentary contexts, it is likely that rapid deposition, or grain transport over short distances, could incorporate grains in which the OSL signal was not zeroed at the time of deposition. Aliquots with outlying higher dose values were therefore excluded from the age calculations, marked as triangles on Fig. 5. The selection of aliquots for both samples was based on omitting those equivalent dose results which lie outside 2 sigma of the mean of the remaining data, and as such, is similar conceptually to the minimum age model. 

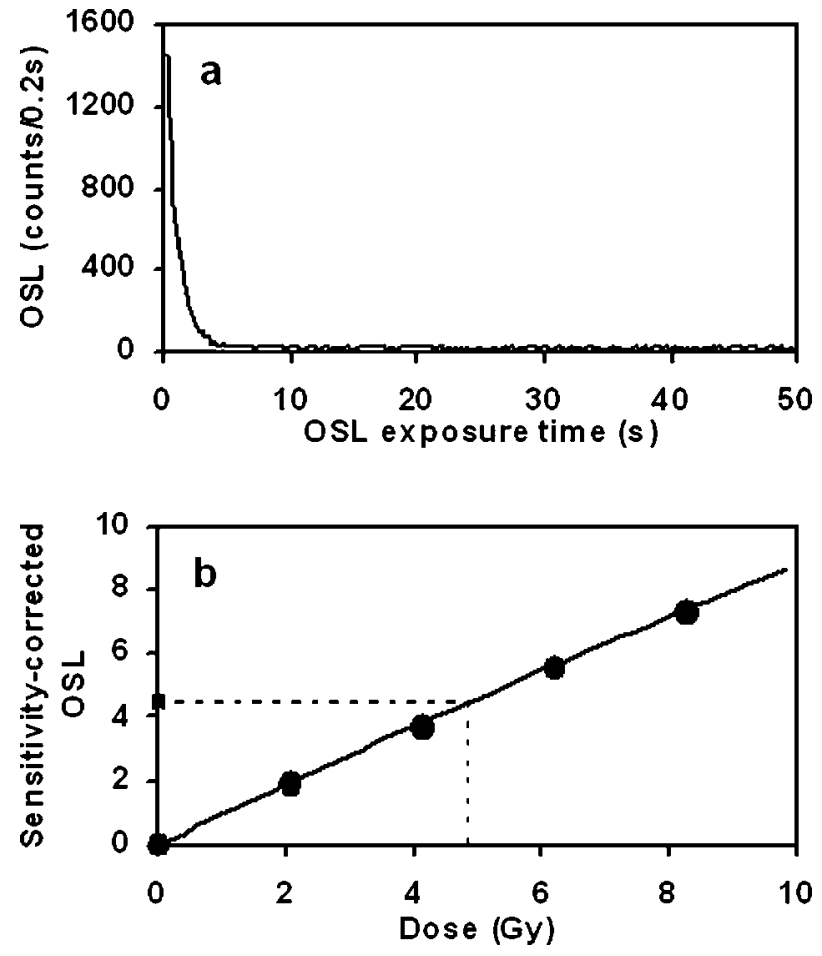

Figure 4 OSL decay curve (a) and sensitivity-corrected regenerative-dose growth curve (b) for an aliquot of sample $\mathrm{X} 1310$

\section{Palaeoecological studies}

Upstream of the gully but extending over the upper part of the sediment fan is a shallow valley mire. This was investigated as part of another project (Fyfe et al. 2004a; 2004b; Rippon et al. 2006) and subjected to pollen analysis. A basal calibrated radiocarbon date of $1920 \pm 60$ yrs BP (c. AD 30) has been obtained (Fyfe et al. 2004a) from the basin upstream of the fan sediments. The pollen data suggests that the valley was still covered by substantial amount of oak with some hazel until a major phase of deforestation $c$. AD 800 (Fyfe et al. 2004a). The dominance of oak over hazel and alder is more pronounced at this site than others in the area and the deforestation is later. It is therefore likely that the woodland in the combe was managed possibly for fuel production by coppicing the hazel and it is possible, but can only be speculated, that oak was being managed for its use as a structural timber in open and adit-type mining. Studies of the charcoal from iron processing sites in the area such as Sherracombe Ford and Bray suggest that woodland was being managed by coppicing in order to provide fuel for ironworking (Juleff and Bray 2007).

\section{Discussion}

In an attempt to explain the anomalous accumulation of sediment within this combe, a survey was undertaken of the catchment. Approximately $150 \mathrm{~m}$ to the north of the site of the gully a linear trench was located (SS 827295-SS 828296, labelled 'mine trench' on Fig. 1) trending north-east, 1-2 m deep and about 1-2 $\mathrm{m}$ in width (Fig. 6a). The trench is not recorded on modern maps, or the 1891 Ordnance Survey $1: 10,560$ County Series, but is visible on aerial photographs taken between 1999 and 2003. This feature is almost certainly due to mining activity and is very similar in form although smaller than the Roman Lode, $9 \mathrm{~km}$ to the north-west at Burcombe (SS 750382) which is regarded by Juleff and Bray (2007) to be a Roman iron mining site (Fig. 6b). There are also several ridges across the strike of the bedrock to the east of the gully that appear very much like prospecting trenches (Carey pers. comm.). There is no obvious sign of mining waste on the slope, but the striking lateral colour change in the silts from the base of stratigraphic $\log 3$ (see Fig. 2) to the streambed to the north may be a result of iron mobilisation. Iron ore in the forms of sideritic (spathic) and hematitic ore found in lodes or veins was mined in the area from the Pickwell Downs Sandstone at Gourt (only $1.25 \mathrm{~km}$ south of the Anstey site), Bampfylde (Poltimore Mine), Molland and near Tabor Hill (New Florence Mine) (Claughton 1997; Edwards 2000). It is also known that there was copper mining in the parish in the 19th century (Claughton 1997). A number of small quarries are marked on the Ordnance Survey 1st edition 6-inch maps, north of Smallacombe and in the valley north of Gourt - in particular a linear eastwest quarry (at SS 823289) similar to the feature shown in Fig. 6. These are thought to be from iron mining trials from the 1870 s (P. F. Claughton pers comm.).

Although alluvial sequences in uplands, on some energetic Midland rivers and even in South-West England, are known to have been affected by Late Holocene climatic change (Brown 1996; Taylor and Macklin 1997; Johnstone et al. 2006; Bennett et al. in press) there are several reasons for discounting this as the forcing mechanism for the deposition of the infill of the Anstey's Combe. Foremost, the adjacent catchments, so similar in all other respects do not contain such sediments and secondly, given the very small size of the catchment $\left(0.4 \mathrm{~km}^{2}\right)$ and the lack of any natural eroding faces, there would appear not to be a natural sediment source. The sequence of sedimentation in the gully appears to have started with erosion of the combe, a process which may have started during the Tertiary, stimulated by local uplift 

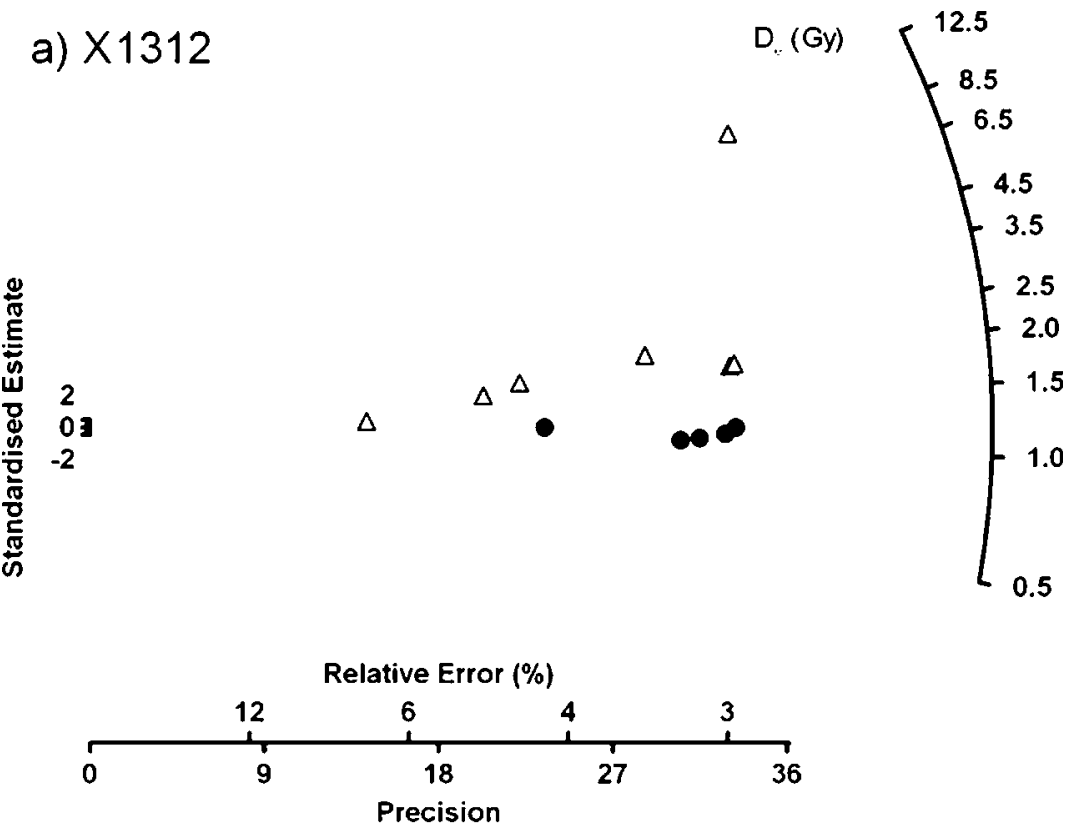

b) $\times 1310$

$D_{.}(G y)$

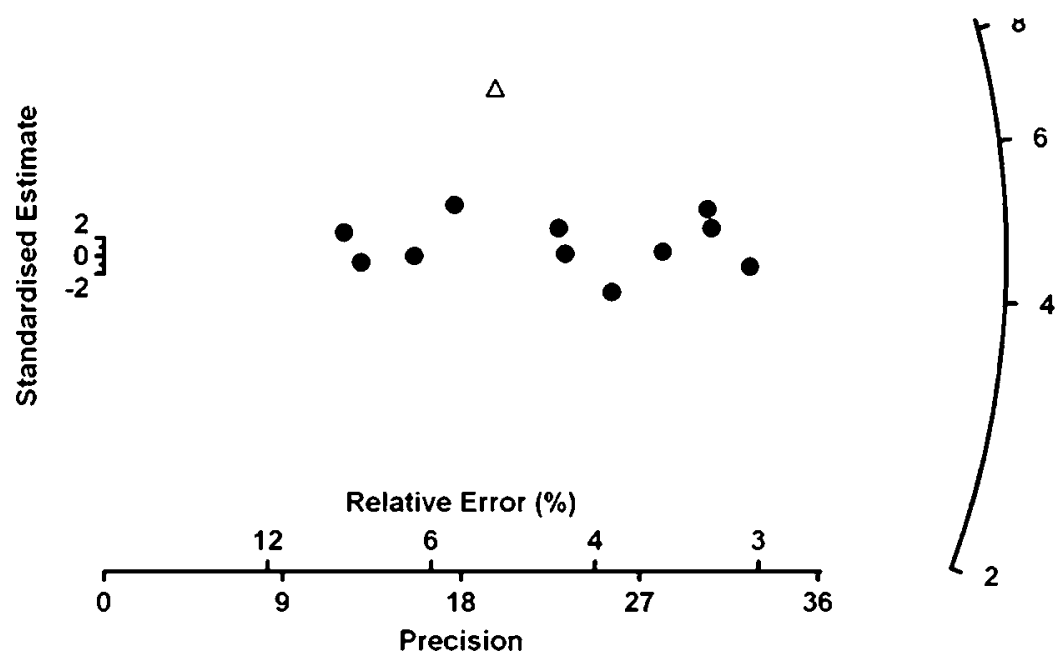

Figure 5 Radial plots of single aliquot SAR OSL data for X1312 (a) and X1310 (b). In both plots, aliquots included in the age calculation are shown as solid circles, while those excluded from the analysis are shown as open triangles

along the Brushford Fault complex (Straw 1995). All the combes discussed here face south, so erosion caused by freeze-thaw and solifluction during periglacial periods of the Pleistocene would have been intense. The disruption of the lowest gravels, showing high angles of dip with weak preferred orientation, is very similar to that seen elsewhere on Exmoor (at Exford, for example) and typical of cryoturbation suggesting that these gravels were deposited late in the Pleistocene with minor incision during the early Holocene (Cant 1974). Above these gravels, the sedimentary deposits are in the form of an alluvial fan, with sedimentation continuing downstream as the fan progrades down the valley. After deposition, a gully was incised revealing the sedimentary layers. Sedimentation in the gully sides shows regular bedding, with alternation of fine and coarse sediments in all except the lowest gravels. 

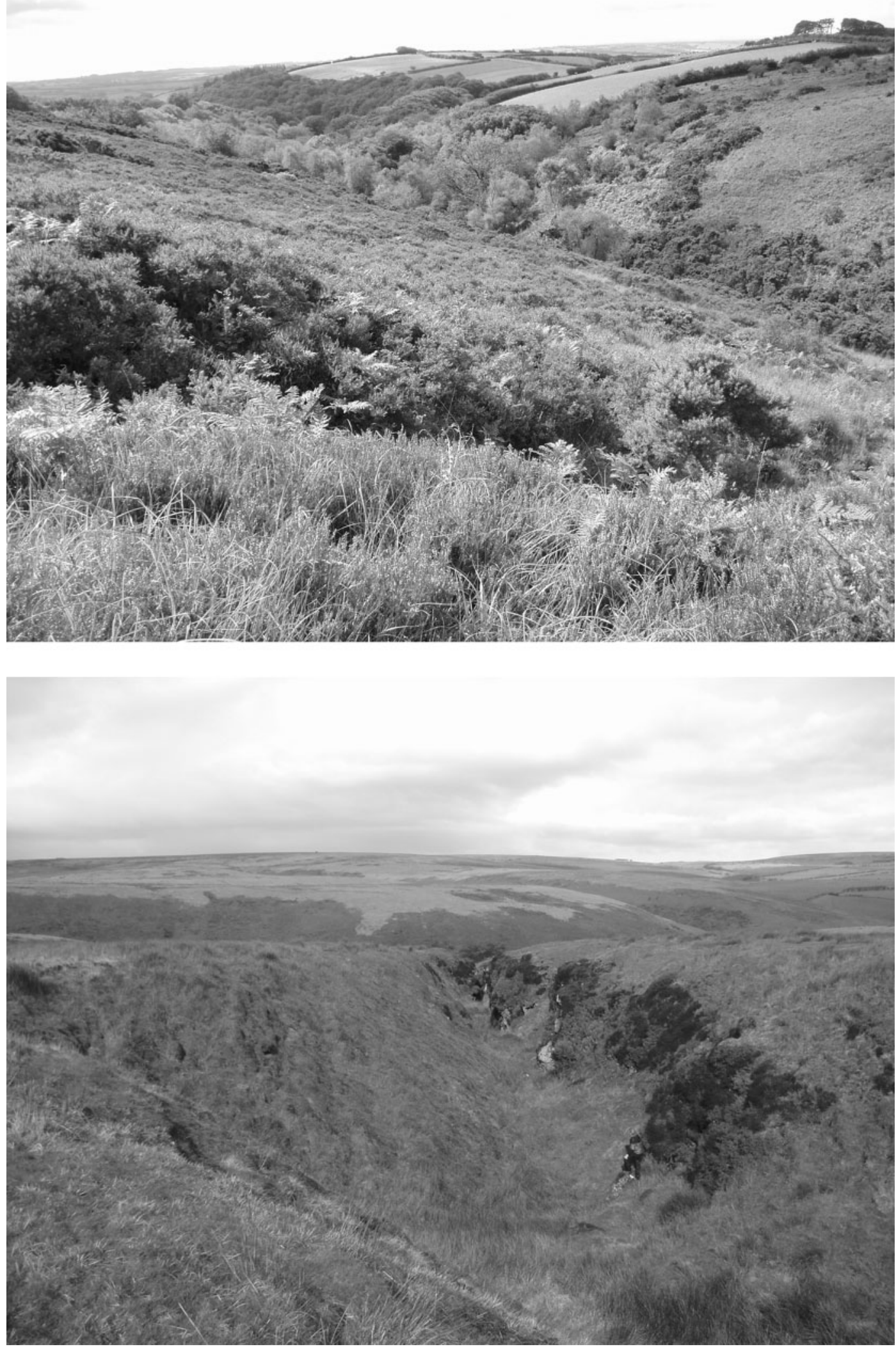

Figure 6 (a) A view down Anstey's Combe with the mining trench in the foreground and the site of the gully under light tree cover in the middle ground. (b) The proposed mining site at Roman Lode. Note the person for scale. Photographs: J. Bennett 


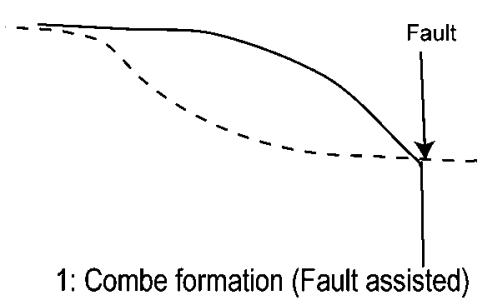

1: Combe formation (Fault assisted)

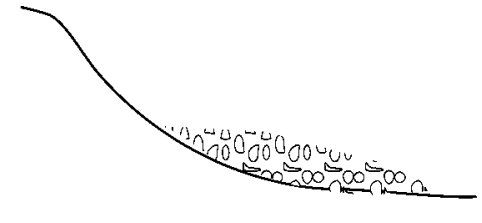

2: Erosion, gravels deposited in bottom of combe, then subjected to later periglacial conditions
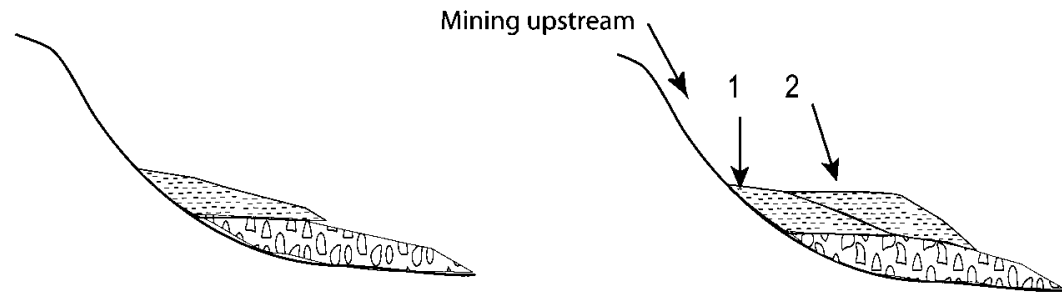

3 and 4: Sediments deposited over gravels (at least two pulses).

1) Roman 2) sixteenth centruy

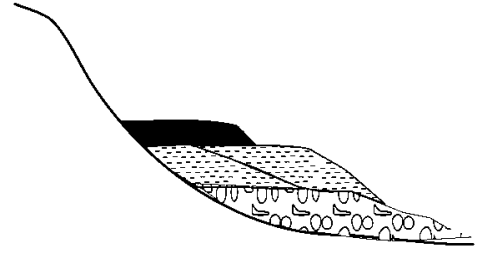

5: Mire formation over early sediments (2000 BP) further sedimentation

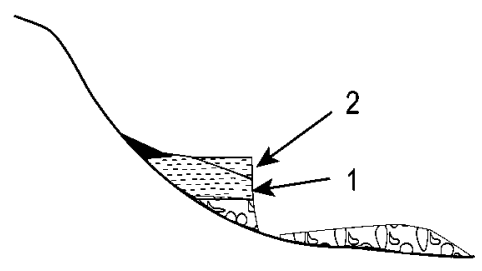

6: Incision, revealing sediments

Figure 7 The evolution of the gully and both climatic and mining induced sedimentation

\section{Conclusions}

The sequence of events at Anstey's Combe is illustrated in Fig. 7. The formation of the original combe was related to the Miocene faulting on the southern edge of Exmoor and subsequent erosion during the Pleistocene. The lower gravels show cryoturbation, and are most likely Lateglacial in age. An alluvial fan gravel formed in the valley due to its geomorphology (increase in valley width) and over-deepening with two phases of fine sediment release over the surface of the valley floor fan. A survey of the small catchment of the combe has revealed a linear feature similar to others identified in the area as due to early, or Romano-British, iron ore mining. Given the small size of the catchment, the anomalous thickness of fine sediments in comparison to its adjacent valleys, and the proximity of the evidence of iron ore mining, it is suggested that the sequence reflects high sediment supply to the valley floor probably in the Romano-British and 16th-17th centuries AD caused by open iron mining. Further work is required at this and other sites in order to refine the chronology and to provide evidence of the mining in situ on the hillsides. This is will be made much easier over the next few years by the combined use of Lidar and geophysical techniques (Brown 2008). However, the study provides the first environmental evidence of probable Romano-British mining on Exmoor and shows that an examination of valley fills can reveal local geomorphological anomalies most likely to be caused by early mining in such metalliferous areas.

\section{Acknowledgements}

The authors must thank Rob Wilson-North and the Exmoor National Park for their assistance and the 
staff of the British Geological Survey Office at Exeter. We also acknowledge the Bill Bishop memorial fund for fieldwork funding for JB.

\section{References}

Atkinson, M. (ed.) 1997. Exmoor's Industrial Archaeology. Tiverton: Exmoor Books.

Banerjee, D., Murray, A. S., Bøtter-Jensen, L. and Lang, A. 2001. Equivalent dose estimation using a single aliquot of polymineral fine grains. Radiation Measurements 33, 73-94.

Bennett, J. A., Brown, A. G. and Schwenninger, J-L. In press. Holocene channel changes and geoarchaeological potential of the Exe river, Devon UK, in Brown, A. G., Basell, L. S. and Butzer, K. (eds.), Geoarchaeology, Climate Change and Sustainability. Geological Society of America Special Volume.

Brown, A. G. 1996. Human dimensions of palaeohydrological change, pp. 57-72 in Branson, J., Brown, A. G. and Gregory, K. J. (eds.), Palaeohydrology and Global Changes: the Context of Palaeohydrology (Geological Society Special Publication No. 115). London: Geological Society.

Brown, A. G. 1997. Alluvial Environments: Geoarchaeology and Environmental Change. Cambridge: Cambridge University Press.

Brown, A. G. In press. Colluvial and alluvial response to land use and climate change in Midland England: an integrated geoarchaeological approach. Geomorphology.

Brown, A. G. 2008. Geoarchaeology, the four dimensional (4D) fluvial matrix and climatic causality. Geomorphology 101, 278-97.

Brown, A. G., Petit, F. and James, A. 2003 Archaeology and human artefacts, pp. 59-76 in Piegay, H. and Kondolf, M. (eds.), Tools in Fluvial Geomorphology. Chichester: Wiley.

Cant, B. 1974. Aspects of valley floor development in the Upper Exe Basin. Reports and Transactions of the Devonshire Association 106, $77-94$.

Claughton, P. 1997. Gourt Mine engine house, pp. 61-65 in Atkinson, M. (eds.), Exmoor's Industrial Archaeology. Tiverton: Exmoor Books.

Coulthard, T. J. and Macklin, M. G. 2003. Modelling long-term contamination in river systems from historical metal mining. Geology 31, 451-54.

Dines, H. G. 1956. The Metalliferous Mining Regions of South West England (Memoir of the Geological Survey of Great Britain). London: HMSO.

Duller, G. A. T. 2008. Luminescence Dating: Guidelines on Using Luminescence Dating in Archaeology. London: English Heritage.

Edwards, R. A. 2000. Exmoor Geology: Exploring the Landscapes, Rocks and Mines of the National Park. Tiverton: Exmoor Books.

Fyfe, R. M., Brown, A. G. and Rippon, S. 2004a. Mid- to lateHolocene vegetation history of Greater Exmoor, UK: estimating the spatial extent of human-induced vegetation change. Vegetation History and Archaeobotany 12, 215-32.

Fyfe, R. M., Brown, A. G. and Rippon, S. J. 2004b. Characterising the late prehistoric, 'Romano-British' and medieval landscape, and dating the emergence of a regionally distinct agricultural system in South West Britain. Journal of Archaeological Science 31, 1699-1714.

Gallagher, C. and Thorpe, M. B. 1995. The fluvial concentrations of heavy minerals in the Slieve Bloom Mountains, Central Ireland. Irish Geography 28, 14-34.

Gilbert, G. K. 1917. Hydraulic mining debris in the Sierra Nevada (US Geological Survey Professional Paper 105). Denver, Colorado: United States Geological Survey.

Goudie, A. S. and Parker, A. G. 1996. The Geomorphology of the Cotswolds. Gloucester: Cotswold Naturalists' Field Club.

Harvey, A. M., Mather, A. and Stokes, M. 2005. Alluvial Fans: Geomorphology, Sedimentology, Dynamics (Geological Society of London Special Publication). Oxford: Blackwell.

Hudson-Edwards, K. A., Macklin, M. G., Finlayson, R. and Passmore, D. P. 1999a. 2000 years of sediment-borne heavy metal storage in the Yorkshire Ouse Basin, northeast England. Hydrological Processes 13, 1087-1102.

Hudson-Edwards, K. A., Macklin, M. G., Finlayson, R. and Passmore, D. P. 1999b. Medieval lead pollution in the River Ouse at York, England. Journal of Archaeological Science 26, 809-13.

Institute of Geological Sciences 1969. Dulverton, England and Wales Sheet 294. Solid and Drift Geology. 1:50,000. London: Institute of Geological Sciences.
Johnstone, E., Macklin, M. G. and Lewin, J. 2006. The development and application of a database of rediocarbon-dated Holocene fluvial deposits in Great Britain. Catena 66, 14-23.

Juleff, G. 1997. Earlier Iron-working on Exmoor: Preliminary Survey. Exmoor National Park Association and National Trust Survey Report.

Juleff, G. 2000. New radiocarbon dates for iron-working sites on Exmoor. HMS News, Newsletter of the Historical Metallurgy Society 44, 3-4.

Juleff, J. and Bray, L. 2007. Minerals, metal, colours and landscape: Exmoor's Roman Lode in the Early Bronze Age. Cambridge Archaeological Journal 17, 285-96.

Knighton, A. D. 1991. Channel bed adjustment along mining affected rivers of northeast Tasmania. Geomorphology 4, 20519.

Macklin, M. G. 1985. Flood-plain sedimentation in the upper Axe Valley, Mendip, England. Transactions Institute of British Geographers 10, 235-44.

Macklin M. G., Rumsby, B. T. and Heap, T. 1992. Flood alluviation and entrenchment: Holocene valley floor development and transformation in the British uplands. Geological Society of America Bulletin 104, 631-43.

Marron, D. C. 1992. Floodplain storage of mine tailings in the Belle Fourche river system: a sediment budget approach. Earth Surface Processes and Landforms 17, 675-85.

Murray, A. S. and Wintle, A. G. 2000. Luminescence dating of quartz using an improved single-aliquot regenerative-dose protocol. Radiation Measurements 32, 57-73.

Murray, A. S. and Wintle, A. G. 2003. The single aliquot regenerative dose protocol: potential for improvements in reliability. Radiation Measurements 37, 377-81.

Rhodes, E. J. 2007. Quartz single grain OSL sensitivity distributions: implications for multiple grain single aliquot dating. Geochronometria 26, 19-29.

Rhodes, E. J., Bronk Ramsey C., Outram, Z., Batt, C., Willis, L., Dockrill, S. and Bond, J. 2003. Bayesian methods applied to the interpretation of multiple OSL dates: high precision sediment age estimates from Old Scatness Broch excavations, Shetland Isles. Quaternary Science Reviews 22, 1231-44.

Rhodes, E. J. and Schwenninger, J.-L. 2007. Dose rates and radioisotope concentrations in the concrete calibration blocks at Oxford. Ancient TL 25, 5-8.

Riley, H. and Wilson-North, R. 2001. The Field Archaeology of Exmoor. London: English Heritage.

Rippon, S. J., Fyfe, R. M. and Brown, A. G. 2006. Beyond villages and open fields: the origins and development of a historic landscape characterized by dispersed settlement in south-west England. Medieval Archaeology 50, 31-70.

Rowan, J. S., Barnes, S. J. A., Hetherington, S. L., Lambers, B. and Parsons, F. 1995. Geomorphology and pollution: the environmental impacts of lead mining, Leadhills, Scotland. Journal of Geochemical Exploration 52, 57-65.

Sellick, R. 1970. The West Somerset Mineral Railway and the Story of the Brendon Hills Iron Mines. 2nd edn. Newton Abbot: Exmoor Books.

Straw, A. 1995. Aspects of the geomorphology of Exmoor, pp. 26-32 in Binding, H. (ed.), The Changing Face of Exmoor. Tiverton: Exmoor Books.

Taylor, M. P. and Macklin, M. G. 1997. Holocene alluvial architecture and valley floor development on the River Swale, Catterick, North Yorkshire, UK. Proceedings of the Yorkshire Geological Society 51, 317-27.

Thorndycraft, V., Pirrie, D. and Brown, A. G. 1999. Tracing the record of early alluvial tin mining on Dartmoor, UK, pp. 91-102 in Pollard, A. M. (ed.), Geoarchaeology: Exploration, Environments, Resources (Geological Society Special Publications 165). London: Geological Society.

Thorndycraft, V. R., Pirrie, D. and Brown, A. G. 2003. An environmental approach to the archaeology of tin mining on Dartmoor, pp. 19-28 in Murphy, P. and Wiltshire, P. (eds.), The Environmental Archaeology of Industry. Oxford: Oxbow Press.

Thorndycraft, V. R., Pirrie, D. and Brown, A. G. 2004. Terrace and floodplain records of medieval and prehistoric tin mining on Dartmoor, SW England. Geoarchaeology 19, 219-36. 